MULTI CONFERENCE ON COMPUTER SCIENCE AND INFORMATION SYSTEMS
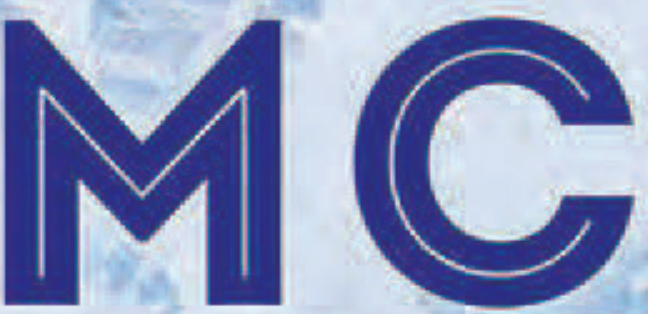

16-19 JULY

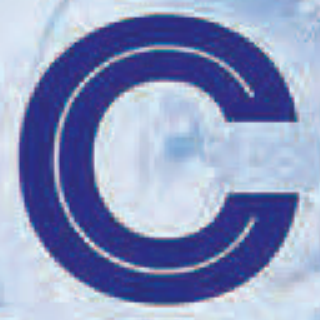

2

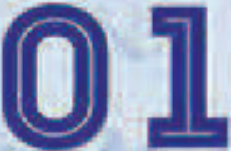

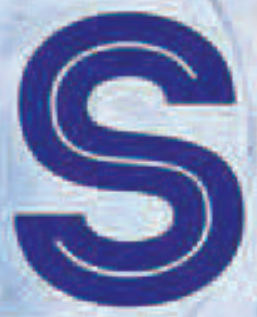
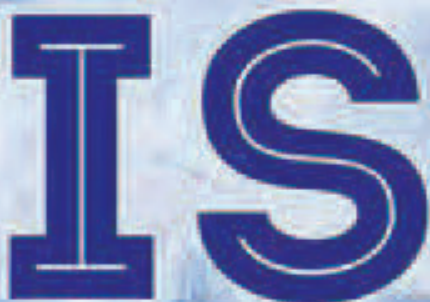

PORTO, PORTUGAL

\title{
Proceedings of the International Conference
}

\section{e-Learning 2019}

Edited by

Miguel Baptista Nunes

Pedro Isaias 


\section{INTERNATIONAL CONFERENCE}

\section{E-LEARNING 2019}

part of the

MULTI CONFERENCE ON COMPUTER SCIENCE

AND INFORMATION SYSTEMS 2019 



\title{
PROCEEDINGS OF THE INTERNATIONAL CONFERENCE
}

\section{E-LEARNING 2019}

\author{
Porto, Portugal \\ JULY 17 - 19, 2019
}

Organised by

international association for development of the information society

Co-Organised by $1010 \begin{aligned} & \text { Instituto Superior de } \\ & \text { Engenharia do Porto }\end{aligned}$ 
Copyright 2019

\section{IADIS Press}

All rights reserved

This work is subject to copyright. All rights are reserved, whether the whole or part of the material is concerned, specifically the rights of translation, reprinting, re-use of illustrations, recitation, broadcasting, reproduction on microfilms or in any other way, and storage in data banks. Permission for use must always be obtained from IADIS Press. Please contact secretariat@iadis.org

Volume Editors:

Miguel Baptista Nunes and Pedro Isaias

Computer Science and Information Systems Series Editors:

Piet Kommers and Pedro Isaias

Associate Editor: Luís Rodrigues

ISBN: 978-989-8533-88-3 


\section{TABLE OF CONTENTS}

FOREWORD $\quad$ xi

PROGRAM COMMITTEE $\quad$ XV

KEYNOTE LECTURE Xix

WORKSHOP $\quad \mathrm{xx}$

\section{FULL PAPERS}

THREE-DIMENSIONAL COLLABORATIVE VIRTUAL ENVIRONMENTS

TO ENHANCE LEARNING MATHEMATICS

Rosa Maria Reis

DO STUDENT RESPONSES DECREASE IF TEACHERS KEEP ASKING

QUESTIONS THROUGH STUDENT RESPONSE SYSTEMS: A QUANTITATIVE RESEARCH

Paul Lam, Carmen K. M. Lau, Kevin Wong and Chi Him Chan

A SEQUENTIAL ANALYSIS OF TEACHING BEHAVIORS TOWARD THE USE OF BLACKBOARD LEARNING MANAGEMENT SYSTEM

Yu-Hang Li, Chien-Yuan Su and Yue Hu

THE IMPACT OF E-LEARNING ON LEARNER KNOWLEDGE SHARING

QUALITY

Sameh M. Reyad, Anjum Razzaque, Sherine Badawi, Allam Hamdan, Reem Khamis and Abdalmuttaleb Al-Sartawi

ASSESSING OPEN-BOOK-OPEN-WEB EXAM IN HIGH SCHOOLS:

THE CASE OF A DEVELOPING COUNTRY

Mary Ann Barbour El Rassi

CRISS: A CLOUD BASED PLATFORM FOR GUIDED ACQUISITION, EVALUATION AND CERTIFICATION OF DIGITAL COMPETENCE

Igor Balaban, Danijel Filipovic and Marko Peras

LEARNING READINESS WHEN SHARING KNOWLEDGE WHILE

E-LEARNING

Anjum Razzaque, Allam M. Hamdan, Mukhtar Al-Hashimi and Esra S. Aldahean

LEARNING RELATED DEVICE USAGE OF GERMAN AND INDIAN

STUDENTS

Joachim Griesbaum, Tessy Thadathil and Sophie März

5G TECHNOLOGY AND ITS APPLICATIONS TO MUSIC EDUCATION 
TEACHER ATTITUDES REGARDING THE USE OF GAME-BASED

PROGRAMMING TOOLS IN K-12 EDUCATION

Yue Hu, Chien-Yuan Su and Yu-Hang Li

THE DYNAMICS OF SUCCESSFUL TEAMS IN A MASSIVE OPEN ONLINE

COURSE

Majd Alomar

MODELS, PROCESS AND TOOL TO ASSIST COOPERATIVE

87

SCENARIZATION OF DISTANT LEARNING MODULES

Christophe Marquesuzaà, Patrick Etcheverry, Pantxika Dagorret, Philippe Lopistéguy,

Thierry Nodenot and Marta Toribio Fontenla

O TEU MESTRE- A DISTANCE LEARNING PLATFORM (RESULTS)

Daniel Azevedo and Paula Morais

COMPARING THREE INPUT DEVICES FOR SKETCHING ASSIGNMENTS

105

IN E-EXAMS IN COMPUTER SCIENCE

Suhas Govind Joshi and Live Armot Brastad

STUDENTS' TEAM-LEARNING INSPIRES CREATIVITY

116

Sayed Jawwad, Mukhtar AL-Hashimi, Anjum Razzaque and Allam Hamdan

FLIPPED CLASSROOM ASSESSMENT: A LEARNING PROCESS APPROACH

Paul Lam, Carmen K. M. Lau and Chi Him Chan

OPEN PROFESSIONAL DEVELOPMENT OF MATH TEACHERS THROUGH

131

AN ONLINE COURSE

Anna Brancaccio, Massimo Esposito, Marina Marchisio, Matteo Sacchet and Claudio Pardini

THE MODERATING ROLE OF M-LEARNING ACTIVITIES

IN THE RELATIONSHIP BETWEEN STUDENTS' SOCIAL CAPITAL

AND KNOWLEDGE SHARING

Marya Ali Al-Ansari, Allam Hamdan, Anjum Razzaque, Sameh Reyad

and Abdalmuttaleb Al-Sartawi

E-LEARNING MODEL FOR TRAINING OF DRIVERS IN TRAFFIC BASED

ON FREQUENT MISTAKES ON THE PRACTICAL EXAM

Goran Jovanov, Jovica Vasiljevic, Nemanja Jovanov, Dejan Antic and Djordje Vranjes

E-LEARNING - EVOLUTION, TRENDS, METHODS, EXAMPLES, EXPERIENCE

Eugenia Smyrnova-Trybulska

IMPACT OF EDUCATIONAL TECHNOLOGY ON STUDENTS'

PERFORMANCE

Maryam Murad, Anjum Razzaque, Allam Hamdan and Anji Benhamed

DESIGN AND IMPLEMENTATION OF AN ENGLISH LESSON BASED

ON HANDWRITING RECOGNITION AND AUGMENTED REALITY

IN PRIMARY SCHOOL

Junyan Xu, Sining He, Haozhe Jiang, Yang Yang and Su Cai

E-LEARNING AND STUDENTS' PERFORMANCE: GENDER PERSPECTIVE

Maryam Murad, Anjum Razzaque, Allam Hamdan and Anji Benhamed

COURSES

André Dietrich

INSTRUCTIONAL DESIGN TO “TRAIN THE TRAINERS":

THE START@UNITO PROJECT AT THE UNIVERSITY OF TURIN

Marina Marchisio, Matteo Sacchet and Daniela Salusso 
Concepción Paz, Eduardo Suárez, Adrián Cabarcos and Christian Gil

A CASE STUDY EXAMINING THE COST MEASUREMENTS IN PRODUCTION

AND DELIVERY OF A MASSIVE OPEN ONLINE COURSE (MOOC)

FOR TEACHING THE RELATIONSHIP BETWEEN HUMAN HEALTH

AND CLIMATE CHANGE

Edward Meinert, Abrar Alturkistani, Kris A Murray, Philippe Sabatier and Josip Car

INCLUSIVE DIGITAL LEARNING THROUGH SERIOUS GAMES: A CLIPPING

FOR INCLUSION

Paula Escudeiro, Dirceu Teixeira, Bruno Galasso, Nuno Neto and Flávio Costa

GAMIFICATION OF IN-CLASSROOM DIAGRAM DESIGN FOR SCIENCE

STUDENTS

Andreas Mallas and Michalis Xenos

"GAMING IN EDUCATION AND E-LEARNING: MOCK-TRIALS,

MOCK-ELECTIONS AND CRISIS-SIMULATIONS FOR POLITICAL SCIENCES AND COMMUNICATIONS COURSES"

Marco Rimanelli and Krzysztof Gurba

\section{SHORT PAPERS}

RESEARCH ON CHANGE AND GROWTH OF STUDENTS AND TEACHERS EXPERIENCED PROBLEM BASED LEARNING

Kyungwon Chang and Seonyoung Jang

TWENTY-FIRST CENTURY INTERVIEWING FOR TWENTY-FIRST CENTURY JOBS. ARE WE PREPARING OUR STUDENTS FOR TODAY'S JOB MARKET? John R. Lax and Ioannis Pantzalis

ONLINE GRADUATE DEGREES: PERCEPTIONS OF MOROCCAN UNIVERSITY STUDENTS

Karima Slamti and Layla Ajrouh

DEVELOPMENT OF AN ONLINE LABORATORY: APPLICATION FOR THE

CHARACTERIZATION OF NTC TEMPERATURE SENSOR

Ameur Ikhlef, Boubekeur Boukhezzar and Nora Mansouri

DIGITAL COMPETENCE IN THE INITIAL TRAINING OF THE

TELESECUNDARIA TEACHER. CASE STUDY

Anna Luz Acosta Aguilera, Rubén Edel Navarro and Yadira Navarro Rangel

LEARNING STRATEGIES THAT CONTRIBUTE TO ACADEMIC EFFICIENCY IN RELATION TO THE BUSINESS SCHOOL STUDENT'S LEARNING STYLES

María de Jesús Araiza Vázquez, Mayra Elizabeth Brosig Rodríguez

and Claudia Ivonne Niño Rodríguez

SOCIAL LEARNING NETWORKING DIGITAL AFFORDANCE DESIGN

Ben Chang and Rotua Zendrato

SECURITY VULNERABILITIES IN MODERN LMS 
EFFECTS OF EPISTEMIC PREPARATIVE ACTIVITIES ON STUDENTS'

UNDERSTANDING IN A FLIPPED CLASSROOM

Wakako Fushikida, Hiroki Oura and Ryo Yoshikawa

DEVELOPMENT OF PROJECT-BASED LEARNING (PBL) IN BLENDED

LEARNING MODE FOR THE ACQUISITION OF DIGITAL COMPETENCE

Olga Arranz-García and Vidal Alonso Secades

PROFUTURO, A SOCIAL INITIATIVE TO IMPROVE EDUCATION WITH

296

E-LEARNING ANALYTICAL TOOLS

Vidal Alonso Secades, Olga Arranz-García and Alfonso Jose López Rivero

DESIGN OF A NEW SCALE TO MEASURE THE LEARNER EXPERIENCE

IN E-LEARNING SYSTEMS

Yassine Safsouf, Khalifa Mansouri and Franck Poirier

APPLICATION OF ALPHA AND BETA BRAINWAVES ON E-LEARNING

PROJECTS IN TERMS OF EXPANDING CRITICAL AND COGNITIVE SKILLS:

AN EXPERIMENTAL APPROACH

Miltiadis Staboulis and Irene Lazaridou

\section{REFLECTION PAPERS}

THE UAV SIMULATION COMPLEX FOR OPERATOR TRAINING

Oleksandr Volkov, Mykola Komar, Kateryna Synytsya and Dmytro Volosheniuk

LANGUAGE ABILITY AND COLLABORATIVE LEARNING

Young Mee Kim

GENERATING GRAPHS IN VIRTUAL REALITY

Simon So

EXPERIENTIAL LEARNING WITH SANSAR PLATFORM - A CONCEPT OF

MILITARY TRAINING

Matgorzata Gawlik-Kobylińska and Pawet Maciejewski

A CRITIQUE OF JACQUES ELLUL (FRENCH PHILOSOPHER) ON

TECHNOLOGY

George A Lotter

MAKING VIRTUAL CLASSROOMS OF GOOGLE PLATFORM MORE REAL

USING TRANSPARENT INTERACTIVE SCREEN-BOARD (tiSb-Albania)

Romeo Teneqexhi and Loreta Kuneshka

FROM STYLES 0 TO STYLE E-0. COGNITIVE STYLES IN E-LEARNING

María Rosa Pinto Lobo

CAN WE DESIGN AND TEACH TO IMPROVE STUDENT PERCEPTIONS OF "COHORT"?

Tom Whitford 


\section{POSTERS}

MIXING EDUCATIONAL TECHNIQUES: E-LEARNING, FLIPPED

CLASSROOM AND THE USE OF SOCIAL NETWORKS. AN EXPERIENCE

IN A UNIVERSITY SETTING

Roberto Espejo Mohedano and Arturo Gallego Segador

USING REN'PY AS A DIGITAL STORYTELLING TOOL TO ENHANCE

STUDENTS' LEARNING

Hsiu-Ling Chen and Yun-Chi Chuang

USING AN ONLINE FORUM TO ENHANCE THE LEARNING OF SPANISH

Jiyoung Yoon

\section{DOCTORAL CONSORTIA}

ORGANISATION OF KNOWLEDGE FROM TRACES OF HUMAN LEARNING PEDAGOGIES

Roy Rozario

\section{AUTHOR INDEX}





\section{FOREWORD}

These proceedings contain the papers of the International Conference e-Learning 2019, which was organised by the International Association for Development of the Information Society and co-organised by ISEP - Instituto Superior de Engenharia do Porto, 17 - 19 July, 2019. This conference is part of the Multi Conference on Computer Science and Information Systems 2019, 16 - 19 July, which had a total of 926 submissions.

The e-Learning (EL) 2019 conference aims to address the main issues of concern within e-Learning. This conference covers both technical as well as the non-technical aspects of e-Learning.

The conference accepted submissions in the following seven main areas: Organisational Strategy and Management Issues; Technological Issues; e-Learning Curriculum Development Issues; Instructional Design Issues; e-Learning Delivery Issues; e-Learning Research Methods and Approaches; e-Skills and Information Literacy for Learning.

The above referred main submission areas are detailed:

\section{Organisational Strategy and Management Issues}

- Higher and Further Education

- Primary and Secondary Education

- Workplace Learning

- Vocational Training

- Home Schooling

- Distance Learning

- Blended Learning

- Change Management

- Educational Management

- Continuous Professional Development (CPD) for Educational and Training Staff

- Return on e-Learning Investments (ROI)

\section{Technological Issues}

- Learning Management Systems (LMS)

- Managed Learning Environments (MLEs)

- Virtual Learning Environments (VLEs)

- Computer-Mediated Communication (CMC) Tools

- Social Support Software

- Architecture of Educational Information Systems Infrastructure

- Security and Data Protection

- Learning Objects

- XML Schemas and the Semantic Web

- Web 2.0 Applications 


\section{e-Learning Curriculum Development Issues}

- Philosophies and Epistemologies for e-learning

- Learning Theories and Approaches for e-learning

- e-Learning Models

- Conceptual Representations

- Pedagogical Models

- e-Learning Pedagogical Strategies

- e-Learning Tactics

- Developing e-Learning for Specific Subject Domains

\section{Instructional Design Issues}

- Designing e-Learning Settings

- Developing e-Learning Pilots and Prototypes

- Creating e-Learning Courses

- Collaborative learning

- Problem-based learning

- Inquiry-based learning

- Blended Learning

- Distance Learning

- Designing e-Learning Tasks

- E-learning activities

- Online Groupwork

- Experiential Learning

- Simulations and Modelling

- Gaming and Edutainment

- Creativity and Design Activities

- Exploratory Programming

\section{e-Learning Delivery Issues}

- e-Delivery in different contexts

- Higher and Further Education

- Primary and Secondary Schools

- Workplace Learning

- Vocational Training

- Distance Learning

- Online Assessment

- Innovations in e-Assessment

- e-Moderating

- e-Tutoring

- e-Facilitating

- Leadership in e-Learning Delivery

- Networked Information and Communication Literacy Skills

- Participation and Motivation in e-Learning 
e-Learning Research Methods and Approaches

- Action Research

- Design Research

- Course and Programme Evaluations

- Systematic Literature Reviews

- Historical Analysis

- Case Studies

- Meta-analysis of Case Studies

- Effectiveness and Impact Studies

- Evaluation of e-Learning Technologies

- Evaluation of Student and Tutor Satisfaction

- Learning and Cognitive Styles

- Ethical Issues in e-Learning

e-Skills and Information Literacy for Learning

- Teaching Information Literacy

- Electronic Library and Information Search Skills

- ICT Skills Education

- in schools and colleges

- for business, industry and the public sector

- in adult, community, home and prison education

- informal methods (peer groups, family)

- Education for Computer-mediated Communication Skills

- Netiquette

- Online safety for children and vulnerable users

- Cybercrime awareness and personal prevention

- Student Production of Online Media

- Web design

- Digital storytelling

- Web 2.0 tools

- etc.

- Digital Media Studies

The e-Learning 2019 conference received 187 submissions from more than 40 countries. Each submission has been anonymously reviewed by an average of four independent reviewers, to ensure that accepted submissions were of a high standard. Consequently, only 30 full papers were approved, which meant an acceptance rate of $16 \%$. A few more papers were accepted as short papers, reflection papers, posters and doctoral consortia. An extended version of the best papers will be selected for publishing in the Interactive Technology and Smart Education (ITSE) journal (ISSN:1741-5659) and also in the IADIS International Journal on WWW/Internet (ISSN: 1645-7641). Other outlets may also receive extended versions of the best papers, including journals from Inderscience.

Besides the presentation of full, short and reflection papers, posters and doctoral consortia, the conference also included one keynote presentation from an internationally distinguished researcher. We would therefore like to express our gratitude to Prof. Jaime Villate, Faculty of Engineering, University of Porto, Portugal, for being the e-Learning 
2019 keynote speaker. Furthermore, the conference featured a workshop entitled "Learning as a Verb: Promoting Active Learning in Higher Education through Effective Design Strategies and Measurement" by Prof. Pedro Isaías, The University of Queensland, Brisbane, Australia and Prof. Paula Miranda, Sustain.RD center, School of Technology, Polytechnic Institute of Setubal, Portugal.

A successful conference requires the effort of many individuals. We would like to thank the members of the Program Committee for their hard work in reviewing and selecting the papers that appear in this book. We are especially grateful to the authors who submitted their papers to this conference and to the presenters who provided the substance of the meeting. We wish to thank all members of our organizing committee.

Last but not the least, we hope that everybody will have a good time in Porto, and we invite all participants for the next years' edition of this conference.

Miguel Baptista Nunes, School of Information Management, Sun Yat-Sen University, Guangzhou, China

Pedro Isaias, The University of Queensland, Australia

e-Learning 2019 Conference Program Co-Chairs

Piet Kommers, University of Twente, The Netherlands

Pedro Isaias, The University of Queensland, Australia

MCCSIS 2019 General Conference Co-Chairs

Bertil Marques, ISEP, Portugal

MCCSIS 2019 Local Organising Chair

Porto, Portugal

July 2019 


\section{PROGRAM COMMITTEE}

\section{E-LEARNING CONFERENCE PROGRAM CO-CHAIRS}

Miguel Baptista Nunes, School of Information Management, Sun Yat-Sen University, Guangzhou, China

Pedro Isaias, The University of Queensland, Australia

\section{MCCSIS GENERAL CONFERENCE CO-CHAIRS}

Piet Kommers, University of Twente, The Netherlands

Pedro Isaias, The University of Queensland, Australia

\section{MCCSIS LOCAL ORGANISING CHAIR}

Bertil Marques, ISEP, Portugal

\section{E-LEARNING CONFERENCE COMMITTEE MEMBERS}

Adamantios Koumpis, Universität Passau Fakultät für Informatik und Mathematik, Germany

Airina Volungevičienė, Vytautas Magnus University, Lithuania Alexandru Vulpe, University Politehnica of Bucharest, Romania Ana Barata, ISEP-GILT, Portugal

Andreas Bollin, Klagenfurt University, Austria

Andreas Papasalouros, University of The Aegean, Greece

Andreja Pucihar, University of Maribor, Slovenia

Andrew Lian, Suranaree University of Technology, Thailand

Ania Lian, Australian Catholic University, Australia

Antoanela Naaji, Vasile Goldis West University of Arad, Romania

Antonio Hervás-Jorge, Universidad Politécnica de Valencia, Spain

Antonio Navarro, Universidad Complutense de Madrid, Spain

Apostolos Gkamas, University Ecclesiastical Academy of Vella of Ioannina, Greece

Ben Chang, National Central University, Taiwan

Bertil Marques, Polytechnic Institute of Porto, Portugal

Charalampos Karagiannidis, University of Thessaly, Greece

Christina Gloerfeld, Fernuniversität in Hagen, Germany

Christos Bouras, University of Patras, Greece

Christos Troussas, University of Piraeus, Greece

Claudia Steinberger, Klagenfurt University, Austria

David Guralnick, Kaleidoscope Learning, USA

Dessislava Vassileva, Sofia University “st. Kliment Ohridski”, Bulgaria

Dimitra Pappa, National Centre of Scientific Research "Demokritos", Greece

Egle Butkeviciene, Kaunas University of Technology, Lithuania

Eliza Stefanova, Sofia University, Bulgaria

Elvis Mazzoni, University of Bologna, Italy

Emma Briend, Mary Immaculate College, Ireland

Erick Araya, University Austral of Chile, Chile

Essaid Elbachari, Cadi Ayyad University, Morocco 
Esteban Vázquez Cano, Spanish National University of Distance Education, Spain

Eva Jereb, University of Maribor, Slovenia

Foteini Grivokostopoulou, University of Patras, Greece

Francesca Pozzi, Instituto Tecnologie Didattiche - CNR, Italy

G.V. Uma, Anna University, India

Gabriela Grosseck, West University of Timisoara, Romania

George Palaigeorgiou, University of Western Macedonia, Greece

George Tsihrintzis, University of Piraeus, Greece

Giuliana Dettori, ITD-CNR, Italy

Hanan Khalil, Mansoura University, Egypt

Ibrahim Ahmed, University of Bahrain, Bahrain

Igor Bernik, University of Maribor, Slovenia

Ingo Dahn, University of Koblenz-Landau, Germany

Ioannis Vardiambasis, Technological Educational Institute (TEI) of Crete, Greece

Isidoros Perikos, University of Patras, Greece

Jane Sinclair, University of Warwick, United Kingdom

Jennifer-Carmen Frey, European Academy of Bozen/Bolzano, Italy

Jesús Sánchez Allende, Universidad Alfonso X El Sabio, Spain

Jirarat Sitthiworachart, Walailak University, Thailand

Jose Bidarra, Open University, Portugal

Jozef Hvorecky, City University of Seattle, Slovakia

Juan M. Alducin-Ochoa, University of Sevilla, Spain Juan M. Santos, University of Vigo, Spain

Katerina Kabassi, TEI of Ionian Islands, Greece

Kateryna Synytsya, Ukraine International Research and Training Center, Ukraine

Katherine Maillet, Institut Telecom \& Management Sudparis, France

Kostas Vassilakis, Technological Educational Institution of Crete, Greece

Lampros Stergioulas, University of Surrey, United Kingdom

Larbi Esmahi, Athabasca University, Canada

Larisa Zaiceva, Riga Technical University, Latvia

Leonardo Garrido, Tecnológico de Monterrey, Mexico

Liodakis George, Technological Educational Institution of Crete, Greece

Luis Álvarez-González, Universidad Austral de Chile, Chile

Luis Anido-Rifón, University of Vigo, Spain

Maiga Chang, Athabasca University, Canada

Manolis Tsiknakis, Forth, Greece

Manuel Caeiro-Rodríguez, University of Vigo, Spain

Maria Moundridou, School of Pedagogical \& Technological Education (ASPETE), Greece

Maria Rigou, Patras University, Greece

Maria Virvou, University of Piraeus, Greece

Marina Rui, University of Genoa, Italy

Mario Vacca, Italian Ministry of Education, Italy

Martin Wessner, Hochschule Darmstadt, Germany

Martín Llamas-Nistal, University of Vigo, Spain

Michael Paraskevas, Computer Technology Institute \& Press, Greece

Michail Kalogiannakis, University of Crete, Greece

Michalis Xenos, University of Patras, Greece

Mihaela Dinsoreanu, Technical University of Cluj-Napoca, Romania

Mizue Kayama, Shinshu University, Japan

Muhammet Demirbilek, Suleyman Demirel University, Turkey 
Natalija Prokofjeva, Riga Technical University, Latvia

Nayna Patel, Brunel University, United Kingdom

Nicola Capuano, DIEM - University of Salerno, Italy

Patrick Blumschein, Teacher University of Freiburg, Germany

Paula Escudeiro, ISEP/GILT, Portugal

Paula Miranda, Polytechnic Institute of Setubal, Portugal

Pavel Rusakov, Riga Technical University, Latvia

Piedade Carvalho, ISEP/GILT, Portugal

Qing Tan, Athabasca University, Canada

Rafael Morales Gamboa, Universidad de Guadalajara, Mexico

Rosa Bottino, CNR, Italy

Rosabel Roig-Vila, Universidad de Alicante, Spain

Roza Dumbraveanu, State Pedagogical University, I.Creanga, Republic of Moldova

Rubén Edel Navarro, Universidad Veracruzana, México

Spiros Sirmakessis, Technological Educational Institution of Western Greece, Greece

Stamatina Anastopoulou, University of the Aegean, Greece

Stanimir Stoyanov, University of Plovdiv, Bulgaria

Tassos A. Mikropoulos, The University of Ioannina, Greece

Thomas Zarouchas, Computer Technology Institute and Press "Diophantus", Greece

Thrasyvoulos Tsiatsos, Aristotle University of Thessaloniki, Greece

Vaiva Zuzeviciute, Mykolas Romeris University, Lithuania

Vassilis Triantafillou, Technological Educational Institution of Messolonghi, Greece

Werner Beuschel, TH Brandenburg, Germany

Xiaokun Zhang, Athabasca University, Canada

Yannis Psaromiligkos, Technological Education Institute of Piraeus, Greece

Yousef Daradkeh, Prince Sattam Bin Abdulaziz University (PSAU) - KS, Saudi Arabia 


\title{
INSTRUCTIONAL DESIGN TO "TRAIN THE TRAINERS": THE START@UNITO PROJECT AT THE UNIVERSITY OF TURIN
}

\author{
Marina Marchisio ${ }^{1}$, Matteo Sacchet ${ }^{2}$ and Daniela Salusso ${ }^{3}$ \\ ${ }^{1}$ Dipartimento di Biotecnologie Molecolari e Scienze per la salute, Università degli studi di Torino, Via Nizza, 52, \\ 10126 Torino TO, Italy \\ ${ }^{2}$ Dipartimento di Matematica “G. Peano”, Università degli studi di Torino, Via Carlo Alberto, 10, \\ 10123 Torino TO, Italy \\ ${ }^{3}$ Dipartimento di Lingue e letterature straniere e culture moderne, Università degli studi di Torino \\ Via Giuseppe Verdi, 10, 10124 Torino TO, Italy
}

\begin{abstract}
Online learning has become essential in higher education. In order to follow the best practices in education and innovation and provide quality of online courses, careful and thorough instructional design is necessary. In this research we analyze the instructional design methods employed and focus on the training of the professors and grant holders who created and developed the 50 open online courses in a variety of disciplines developed in the start@ unito project, a recent enterprise of the University of Turin with the aim of bridging the gap between secondary and higher education and provide open online courses that can be accessed anytime anywhere. The data gathered from the questionnaires given to the grant holders before and after the training show encouraging results as far as the effectiveness of our instructional method is concerned. At the same time, though, they reveal a lack and a disparity of technical, pedagogical and linguistic competences, which in turn require tailored and individualized support. In light of the feedback received, we conclude by envisaging possible improvements and further research, in order to understand what can be done to perfect the instructional design of an ever-expanding project.
\end{abstract}

\section{KEYWORDS}

Digital Education, Educational Technology, e-Learning, Instructional Design, Open Online Courses, Teacher Training

\section{INTRODUCTION}

It is an undeniable fact that online learning has become essential in higher education, not only as a way to showcase the university's programmes and departments, but also and especially to contribute knowledge to the world, enhance teaching and learning, promote internationalization, facilitate working students and ease the transition from high school to university, following the best practices in education and innovation.

The University of Turin has recently embarked upon the start@unito project (Bruschi et al., 2018; Marchisio et al., 2019), financed by Compagnia di San Paolo and aimed at using the Moodle LMS to create and provide open online courses targeted at both university students and high-school students in their last year. Before start@unito, the University of Turin had already had experience in developing high-quality online teaching programs, such as PPS Problem posing and solving (2012) (Brancaccio et al., 2015; Barana et al., 2019), aimed at high-school teachers of STEM disciplines, the Scuola dei compiti project (2013) (Barana et al., 2017c) as a support for high-school students, and the university guidance modules Orient@mente (2014) (Barana et al., 2017a; Barana, et al., 2016; Barana, et al., 2017b). In addition, it is worth mentioning the Foundation Programme (2018), aimed at foreign students who wish to learn Italian and earn the credits required to study at the University of Turin. So far, the university offers 20 online courses across a wide range of subjects, and 30 additional courses will be available.

In the first phase of the project start@unito (academic year 2017-2018), 20 online courses were created, developed and implemented. The disciplines covered belong to the scientific (e.g. Physics, Mathematics, Informatics, Zoology, etc.), the legal (e.g. Political Science, Law and Justice, European institutions and rights, 
etc.), the economic (Economics and firms) and the humanistic (e.g. Philosophy, Contemporary History, etc.) area. The second phase of the project is currently undergoing. This year 30 additional online courses are being prepared and will be available soon. In addition to the areas covered the previous year, some linguistic disciplines have been added (e.g. English Language and Linguistics, German Language, Swahili Literature), as well as many courses taught completely in English.

Throughout these experiences in designing and helping others design online courses, we came across a major difficulty, namely the resistance towards changing one's didactic approach. Especially when dealing with established University Professors, who have been perfecting their materials and their teaching methods for a long time, it is often challenging to adopt the more student-centered, modular, multimodal and interactive approach that the online context demands. The technical, pedagogical and methodological skills required cannot be learned overnight, therefore our team decided to offer a course to "train the trainers". The course was composed of 12 in-person meetings, in which the main topics of e-learning were presented and discussed by experts (University professors and technical staff): how to design an online course, how to communicate effectively with videos, how to use the online platform, the Automated Assessment System (AAS) and some software for creating digital contents. Somme issues about copyright, accessibility and HTML language were presented to make professors more aware of the context of Digital Education. The training was supported by an online course where all the materials presented were available, together with additional resources.

The professors were supported by postgraduate grant holders, each experienced in the subject of study and with some background experience in using learning management systems, video making, and online teaching. Ideally, the training programme was conceived for both professors and grant holders, but in practice, given the numerous academic commitments, the grant holders' participation was much higher. For this reason, we will focus on the analysis of their training. Our aim is precisely to evaluate and interpret the data gathered from the questionnaires given to grant holders in order to self-reflect on our instructional design choices. We will briefly review the relevant literature on instructional design and present the theoretical framework within which we operated. After that, the methodology, the model and the data will be discussed. The results show that our instructional design model proved indeed to be effective in facilitating the transition between classroom and online teaching. However, it also emerged that the initial low and very uneven technical and linguistic competences would require a more practical approach, personalized support and differentiated training, especially among different subjects. Personalized guidance also seems to be beneficial in understanding how to put together the pedagogy and the technology.

\section{BRIEF LITERATURE REVIEW}

As the demand for online distance courses gradually increases in the academic world, so does the need for a professional figure that can help professors throughout transition from face-to-face courses to online ones. An analysis of the topic "instructional design and technologies" reveals that lately it has become one of the most popular among scholars (Hsu, 2012; West, 2017) as well as teacher education and training (West, 2014; West 2017). Although many authors have suggested a constructivist approach to distance education (Crotty, 1994; Garrison, 1993), very few have proposed clear, specific strategies to put it into practice. The majority of experts, nevertheless, agree on one point: the need to replace the usual teacher-centered paradigm in favor of a more student-centered one, which employs the technologies available in order to create a learning environment that supports the knowledge construction process (Barr and Tagg, 1995; Taylor, 2000). This model has often been referred to as constructive alignment. The concept of constructive alignment dates back sixty years (Tyler, 1949) but it has recently been applied to the higher education online context (Biggs, 2014). Biggs contends that in the transition between a teacher-centered design of courses to a more student- and outcome-based one, constructive alignment needs to be embedded in a supportive culture in order to work properly at the departmental, institutional and even national levels. As for a model that would allow a smoother transition, Biggs and Tang (Biggs, and Tang, 2011) describe a "training the trainers" model.

The discipline concerned with training the trainers is instructional design, whose aim is to create a stimulating learning environment where learners can actively interact with contents and knowledge transmitted via a teacher or interactive material, thus supporting learning as an active process of constructing (Duffy and Cunningham, 1996). Instructional design aims at training the trainers on how to design those materials and how to use the technologies available to match their educational purposes, assisting teachers and tutors by 
providing them with a set of principles and concept models (Wilson, 1996). Instructional designers in higher education "use a wide variety of tools for a wide variety of purposes ranging from course design to supporting faculty in delivering online courses to facilitating meaningful workshops for faculty" (Kumar and Ritzhaupt, 2017). Furthermore, instructional design has been defined as the sector that operates at the international level to identify the didactic criteria and models applicable in the different contexts, in such a way that learning has the highest possible probability to be effective, efficient, and interesting (Calvani and Menichetti, 2015). Despite the popularity of online courses such as MOOCs, however, very little study has been carried out consistently on the quality of instructional design in those courses (Margaryan, Bianco, and Littlejohn, 2015), whereas we believe it to be a key component and an essential prerequisite of the potential for effective learning but also for effective teaching. Many scholars, among whom Speck (Speck, 2000), noted that, these changes in higher education often disregard academics' pedagogical expertise. Online teaching is a relatively new field for most university professors, and without careful training that also includes the pedagogical aspects, they may end up perceiving "greater intrinsic and extrinsic barriers" when approaching it (Lloyd et al., 2012). Therefore, we have designed a training course that takes into account all of these factors; in the following chapter we will outline the basic principles of our own instructional design method.

\section{THEORETICAL FRAMEWORK AND RESEARCH QUESTIONS}

Our main goal was to find a set of clear principles on which to base our training course, following a method that puts together the pedagogy and the technical aspects.

After the first tentative year of start@unito, in which the basic theoretical principles were laid out, a more in-depth analysis followed, and a more structured program was implemented. According to this program, the instructional designers' task is to structure a training course based on the following theoretical grounds:

- $\quad$ Course structure: modular structure of courses (Rogerson-Revell, 2007) with a grid format and each section corresponding to an ECTS, organized in learning objects that comply with the LTSC standards; mindful engagement of students in tasks and in the interaction with the learning-objects (Bruschi and Perissinotto, 2003). The design process took an important role prior to any implementation: professors and grant holders had to clearly outline the structure, specifying which concept to be explained and how. Comparison between different courses must be encouraged, in order to make the quantity of materials homogeneous.

Use of technology: principles of multimedia learning (Mayer, 2005; 2014) that support integration between text, image and voice in order to adapt the cognitive load (Plass et al., 2010) of the contents to learn. Materials organized according to the principles of segmentation, sequencing, and pacing. Prior experience on the use of technology for learning at the University of Turin was taken into account, especially in the choice of the online platform in which the courses are hosted.

Learning outcomes: constructive alignment of learning outcomes. Instructional design must adapt the cognitive load by diminishing the external one and optimizing the intrinsic one according to the attainment target (Landriscina, 2015).

Assessment: formative assessment and feedback to enhance teaching and learning and provide self-regulation (Barana et al., 2018; Bloom, 1971) paired with automated assessment and adaptive methodologies (Barana et al., 2015; Hattie and Timperley, 2007) especially for scientific subjects.

A variation of the ADDIE model of instructional design based on a five-phase project: Analyze, Design, Develop, Implement, and Evaluate.

Once the theoretical principles were outlined, we designed our training programs, whose aim was to prepare grant holders and professors to create online courses based on such principles. For the purpose of the present paper, we decided to focus on grant holders because, not being burdened by academic commitments, they were the ones who actually participated in the whole training. Secondly, the professors have more expertise in terms of contents and didactics, but fewer in terms of technical skills. In light of the feedback received, our research question is how effective the training actually was in proposing a coherent instructional design method and what may be done to improve it. 


\section{METHODOLOGY}

The methodology we adopted for this research relies on three modalities of data collection:

1) The specific issues that emerged and were discussed during the training course. The subjects covered in the training, during traditional lessons and/or laboratories, ranged from online pedagogy and assessment techniques, to basics of videomaking and practical use of the Moodle platform, from editing, automatic assessment and advanced computing environment software, to copyright and website accessibility. All the lessons were held by experts in their field.

2) The questionnaires administered both before and after the training course: all the 29 grant holders with whom we worked this year replied. We chose to distribute the questionnaires online and we opted for a non-anonymous survey, as we were interested in understanding the points of view of each individual and be able to relate the criticalities encountered to their subject of study. The pre-training and the post-training questionnaires were structured in the same way; the questions - a mix of multiple selection, Likert Scale, and open questions - were repeated to maximise the potential for comparison. Furthermore, the post-training questionnaire also contained a set of questions about the self-study materials (lesson recordings, tutorials, manuals, templates, etc.) that we provided.

3) The individual and group support we offered throughout the creation of the courses, aiming at solving problems and finding solutions together, as well as promoting dialogue between grant holders, professors, the technical staff and the scientific committee. We offered support in the form of official monthly group meetings where grant holders presented their materials and discussed their effectiveness with us. These meetings were attended by the technical staff too, who offered advice whenever needed; on-request one to one meetings in our office and or on-site for both professors and grant holders who wished to be counselled or supported on specific issues; daily support via e-mail and phone to solve the most pressing problems.

\section{DATA AND REFLECTIONS}

After examining the answers to the questionnaire given to the grant holders at the beginning and at the end of the experience, two main trends can be noticed.

First of all, a general lack of technical competence before the training and only a passive knowledge and understanding of the e-learning environment emerge. 57,14\% of grant holders had already had some experience of e-learning as students: many grant holders studied at the University of Turin, where many departments have been adopting e-learning strategies since 2004 . Nevertheless, only $24,14 \%$ had had the same experience as tutors and as provider of education through an online platform. In addition, 51,72\% were already familiar with the concept of Virtual Learning Environment (VLE), whereas only 27,59\% were aware of what an Automated Assessment System (AAS) is and how it works. This shows that even if some people used an online tool for learning, they may not have been aware of all its potentialities. The lessons belonging to the technical area were also the ones considered the most useful. Some of the open answers also confirm the same trend; the question "what are your expectations of this training course?" generated such answers as "understanding the e-learning world, learning how to improve my technical skills, learning how to use the Moodle platform, an introduction to the VLE, learning about the software available to design online courses." Some grant holders expected more examples of online learning materials, especially for specific humanistic disciplines. About this, after an introductory meeting to show the start@ unito project with its objectives and its outcomes, we let grant holders freely navigate the web to clear their mind about how their subjects is presented in online materials. Two questions were about personal experience on three different areas: technical, organizational and didactic areas, before and after the training. As we can see in Table 1 below, the medium level of competence in the technical area was rather low before the training, while the median for the level of competence in the organizational and didactic areas was average. Less than $50 \%$ of the answers were "average" or above in the technical area, while around $40 \%$ of the answers were "Good" or "Very good" in the organizational and didactics areas. 
Table 1. Level of competence in the three areas of expertise before the training

\begin{tabular}{cccc}
\hline $\begin{array}{c}\text { Level of } \\
\text { competence }\end{array}$ & $\begin{array}{c}\text { Technical } \\
\text { area }\end{array}$ & $\begin{array}{c}\text { Organizational } \\
\text { area }\end{array}$ & $\begin{array}{l}\text { Didactic } \\
\text { area }\end{array}$ \\
\hline No competence & $17,24 \%$ & $6,90 \%$ & $10,34 \%$ \\
Low & $37,93 \%$ & $13,79 \%$ & $24,14 \%$ \\
Average & $31,03 \%$ & $37,93 \%$ & $24,14 \%$ \\
Good & $13,79 \%$ & $34,48 \%$ & $37,93 \%$ \\
Very good & $0,00 \%$ & $6,90 \%$ & $3,45 \%$ \\
\hline
\end{tabular}

Secondly, the instructional design training had a positive impact: when asked how ready they felt to create and develop and online course, $48.3 \%$ of grant holders reported feeling almost ready to start designing it before the formative lessons. After the training, though, only 20,7\% of grant holders reported feeling almost ready, while $55,2 \%$ reported feeling ready enough and $24,1 \%$ very ready. Nobody reported not feeling ready. The training also proved to be effective to improve the perceived competence of the grant holders in the three main areas of expertise required. The technical area, in particular, in which more than a half of grant holders were lacking, reported a consistent improvement, because the median is Good. It must be noticed that the median improved in all three areas to Good, more than $60 \%$ of the answers attested Good or Very good and, luckily, no grant holders selected No competence. Detailed results are shown in Table 2.

Table 2. Level of competence in the three areas of expertise after the training

\begin{tabular}{cccc}
\hline $\begin{array}{c}\text { Level of } \\
\text { competence }\end{array}$ & $\begin{array}{c}\text { Technical } \\
\text { area }\end{array}$ & $\begin{array}{c}\text { Organizational } \\
\text { area }\end{array}$ & $\begin{array}{l}\text { Didactic } \\
\text { area }\end{array}$ \\
\hline No competence & $0,00 \%$ & $0,00 \%$ & $0,00 \%$ \\
Low & $10,34 \%$ & $13,79 \%$ & $17,24 \%$ \\
Average & $17,24 \%$ & $24,14 \%$ & $17,24 \%$ \\
Good & $41,38 \%$ & $48,28 \%$ & $44,83 \%$ \\
Very good & $31,03 \%$ & $13,79 \%$ & $20,69 \%$ \\
\hline
\end{tabular}

It is worthwhile to mention that grant holders participated in an average of 9.27 in-person meetings over 12. Grant holders were asked about the usefulness of each meeting via a 5-point Likert scale ( $1=$ Not useful, $5=$ Very useful). The average score was 4 , quite useful, again with higher points on technical meetings. After the in-person training, all grant holders expressed an improvement in their skills (median 4 out of a 5-point Likert scale) and reported feeling ready to prepare an online course with their professors (median 4 out of a 5-point Likert scale with $100 \%$ of the data with score 3 or above), thus the formative lessons had a big influence on the way they prepared their materials and 17,2\% reported being highly influenced. The online support materials that were particularly appreciated are tutorials, manuals, templates and sample materials. Nevertheless, the open question regarding which aspects of the training course may be improved highlighted the widespread necessity for a more practical, hands-on approach, focusing on specific issues, promoting learning-by-doing strategies and providing more examples of how to create quality contents and a good course structure. Furthermore, many grant holders expressed the need for targeted and tailored interventions, concentrating on the critical areas of each subject rather than attending group lessons or laboratories. This conclusion is in line with our observations throughout the academic year, since we also offered one-to-one meetings and personalized technical, didactic and linguistic support. According to the data gathered from the questionnaire and our considerations, the main areas in which grant holders needed individualized and differentiated training were: 
- the technical area: as mentioned before, there was a general low level of technical competences in the required sub-categories: video-making, using Maple TA automated assessment, managing and making the most of the tools offered by the VLE Moodle, creation of multimedia contents such as screencasts and interactive pdfs, using an Advanced Computing Environment (ACE) and rudiments of HTML. However, it must be pointed out that those grant holders who already had a technical-scientific background, especially in Mathematics, were accustomed to using most of the tools proposed or simply more inclined to learning the basics easily. On the contrary, those whose subjects belonged to the humanistic, linguistic or legal areas found it difficult to cope with the specificity of the training and to reflect on how some of the tools proposed may be effectively used in a non-scientific context. One example is adaptive feedback, made possible when designing tests with Maple TA. Some grant holders and professors of linguistic subjects, for example, saw the potential of the adaptive features in an asynchronous context where the language student does not have the opportunity for interacting either with a tutor or with peers, but only few of them used it because they lacked the time to learn how to use the tool effectively. Similarly, 69\% of grant holders revealed that they had no need to use an ACE to build their interactive materials, and their follow-up answer on the reason why they did not need it made it clear that it was not due to a lack of interest or skills, but the subject did not require the ACE.

- The pedagogical area: many professors and grant holders struggled with shifting the teaching paradigm to a more student-centered one, and found it challenging to rethink contents and materials. In particular, some of the open answers in the post-training questionnaire revealed that the pedagogical differences between designing an online course for the bachelor's and one for the master's degree had not been accounted for enough.

- The linguistic area: most grant holders and professors who worked on courses held entirely in English required systematic linguistic support. The professors had already received EMI training for their traditional classroom courses held in English, but the online context generated further complications, such as the necessity to create materials from scratch because of copyright issues, and the need to speak in front of the camera in one's second language.

Finally, the last part of the post-training questionnaire focused on the online support materials we provided. One of our aims, in fact, is to perfect a self-study online programme based on the same instructional design principles of the traditional training, which can accompany and guide professors and grant holders in their journey. We asked our participants if they would recommend the use of the online materials only to prepare for the creation of an online course, and $41,4 \%$ of grant holders said yes. The remaining $58.6 \%$ explained their position in the comments: they said that despite finding the self-study materials very useful, the face-to-face time to exchange ideas, discuss problems and find solutions both with their peers and with us was invaluable.

However, many of them agreed that most of the materials provided were a good alternative to attending the lesson, as long as the element of interaction is always present, either as an online tutoring format or as individual meetings after the general training course has been completed.

\section{CONCLUSION}

Thanks to the feedback received, the observations made, and the results obtained, we can learn from our experience and reflect on how a self-study training course should be organized in order to achieve the ultimate goals of the instructional design model presented.

First, training courses may consist in a general, common part that, following the instructional design Addie Model, may correspond to the "analysis" phase. After this first phase, though, before starting the actual "design" phase, some room for individual and tailored support must be available. In fact, early prediction and identification of problem areas may avoid an imbalance between course content and course design, as well as the technology used and their effectiveness, bearing in mind the learning outcomes. To partially solve this problem, we provided some common general training modules, both in person and online. Then, the trainer can choose between different paths, according to whether the online course is held in Italian or in English, whether it is aimed at students of the bachelor's or the master's degree, and whether the subject in question is scientific, linguistic, legal, economic, humanistic or other. Another way to give individual support consists in providing users with content models, ready to be shared, cloned and adapted to the instructional need. By 
providing personalized guidance in the early stages of the course design, we expect the development of materials to be easier and smoother, and as a consequence, teachers' and grant holders' confidence to improve. We will continue to investigate the results after the implementation and the evaluation phases take place. So far, our experience reveals that in order to "train the trainers" in higher education in order to facilitate the transition between traditional classroom teaching and online teaching, we need the flexibility to rethink content creation, teaching methods, and assessment techniques, maintaining the same quality yet at the same time accounting for the fact that we are working in a different environment.

\section{REFERENCES}

Barana, A., Bogino, A., Fioravera, M., Floris, F., Marchisio, M., Operti, L., Rabellino, S.2017a. Self-paced approach in synergistic model for supporting and testing students: The transition from Secondary School to University. Proceedings of 2017 IEEE 41st Annual Computer Software and Applications Conference (COMPSAC), pp. 404-409.

Barana, A., Bogino, A., Fioravera, M., Marchisio, M., Rabellino, S., 2016. Digital Support for University Guidance and Improvement of Study Results. Proceedings - Social and Behavioral Sciences 228, pp. 547-552.

Barana, A., Bogino, A., Fioravera, M., Marchisio, M., Rabellino, S., 2017b. Open platform of self-paced MOOCs for the continual improvement of academic guidance and knowledge strengthening in tertiary education. Journal of e-Learning and Knowledge Society, 13(3), 109-119.

Barana, A., Brancaccio, A., Conte, A., Fissore, C., Floris, F. Marchisio, M. Pardini, C., 2019. The Role of an Advanced Computing Environment in Teaching and Learning Mathematics through Problem Posing and Solving. Proceedings of the 15th International Scientific Conference eLearning and Software Education (ELSE 2019), Bucarest, vol. 2, pp. 11-18.

Barana, A., Fioravera, M., Marchisio, M., Rabellino, S., 2017c. Adaptive teaching supported by ICTs to reduce the school failure in the Project "Scuola dei Compiti", Proceedings of 2017 IEEE 41st Annual Computer Software and Applications Conference (COMPSAC), pp. 432-437.

Barana, A., Conte, A., Fioravera, M., Marchisio, M., Rabellino, S., 2018. A Model of Formative Automatic Assessment and Interactive Feedback for STEM. Proceedings of 2018 IEEE 42nd Annual Computer Software and Applications Conference (COMPSAC), Tokyo, Japan, pp. 1016-1025.

Barana, A., Marchisio, M., Rabellino, S., 2015. Automated Assessment in Mathematics. Proceedings of 2015 IEEE 39th Annual Computer Software and Applications Conference, Taichung, Taiwan: IEEE, pp. 670-671.

Barr, R. B., and J. Tagg, 1995. From teaching to learning - A new paradigm for undergraduate education. Change, pp. 13-25.

Biggs, J., 2014. Constructive alignment in university teaching. HERDSA Review of Higher Education Vol. 1, Hammondville, Australia, pp. 5-22

Biggs, J., and Tang, K., 2011. Teaching for quality learning at University. 4th ed. Maidenhead: Oxford University Press.

Bloom, B., Madaus, G. F., and Hastings, J. T., 1971. Handbook on Formative and Summative Evaluation of Student Learning. New York: McGraw-Hill.

Brancaccio, A., Marchisio, M., Palumbo, C., Pardini, C., Patrucco, A., Zich, R., 2015. Problem Posing and Solving: Strategic Italian Key Action to Enhance Teaching and Learning Mathematics and Informatics in the High School. In: Proceedings of 2015 IEEE 39th Annual Computer Software and Applications Conference (COMPSAC), IEEE, Taichung, Taiwan, pp. 845-850.

Bruschi, B., Cantino, V., Cavallo Perin, R., Culasso, F., Giors, B., Marchisio, M., Marello, C., Milani, M., Operti, L., Parola, A., Rabellino, S., Sacchet, M., Scomparin, L., 2018. Start@unito: a Supporting Model for High School Students Enrolling to University. IADIS International Conference Cognition and Exploratory Learning in Digital Age 2018, pp. 307-312.

Bruschi, B., and Perissinotto, A., 2003. Come creare corsi on line. Carocci, Roma.

Calvani, A., and Menichetti, L., 2015. Come fare un progetto didattico. Carocci, Roma.

Crotty, T., 1994. Integrating distance learning activities to enhance teacher education toward the constructivist paradigm of teaching and learning. Distance Learning Research Conference Proceedings, 3, pp. 1-37. College Station, TX: Department of Education and Human Resource Development, Texas A \& M University.

Duffy, T. M., and Cunningham, D. J., 1996. Constructivism: Implications for the Design and Delivery of Instruction. Handbook of Research for Educational Communications and Technology. Macmillan Library Reference, New York, USA.

Hattie, J., and Timperley, H., 2007. The Power of Feedback. Review of Educational Research, Vol. 77(1), pp. 81-112. 
Garrison, R., 1993. Quality and access in distance education: Theoretical considerations. Theoretical Principles of Distance Education, pp. 9-2 1, Routledge, New York.

Hsu, Y.-C., Ho, H. N. J., Tsai, C.-C., Hwang, G.-J., Chu, H.-C., Wang, C.-Y., and Chen, N.-S., 2012. Research trends in technology-based learning from 2000 to 2009: A content analysis of publications in selected journals. Educational Technology \& Society, Vol. 15(2), pp. 354-370.

Kumar, S \& Ritzhaupt, Albert., 2017. What do instructional designers in higher education really do?. International Journal on E-Learning: Corporate, Government, Healthcare, and Higher Education. 16. 371-393.

Landriscina, F., 2015. Instructional Design e progettazione curricolare. Un binomio possibile per la scuola italiana. Form@re. Open Journal per la formazione in rete, $\mathrm{Vol} 15, \mathrm{~N}^{\circ} 3$.

Lloyd, S. A., Byrne, M. M., \& McCoy, T. S., 2012. Faculty-perceived barriers of online education. Journal of Online Learning and Teaching, 8(1), 1-12.

Margaryan, A., Bianco, M., and Littlejohn, A., 2015. Instructional quality of Massive Open Online Courses (MOOCs). Computers \& Education 80, pp. 77-83.

Marchisio, M., Operti, L., Rabellino, S., Sacchet, M., 2019. Start@unito: Open Online Courses for Improving Access and for Enhancing Success in Higher Education. Proceedings of the 11th International Conference on Computer Supported Education (CSEDU 2019), Heraklion, Crete, Greece, pp. 639-646.

Mayer, R. E., 2005. Cognitive Theory of Multimedia Learning. The Cambridge handbook of multimedia learning. New Cambridge University Press, York, NY, US pp. 31-48.

Mayer R. E., Lee H. and Peebles A., 2014. Multimedia Learning in a Second Language: A Cognitive Load Perspective, Applied Cognitive Psychology 28, pp. 653-660

Plass, J. L., Moreno, R., and Brünken, R. (Eds.), 2010. Cognitive load theory. Cambridge University Press, New York.

Rogerson-Revell, P., 2007. Directions in e-learning tools and technologies and their relevance to online distance language education. Open Learning 22(1), pp. 57-74.

Speck, B. W., 2000. The academy, online classes, and the breach in ethics: Principles of effective teaching in the online classroom. New Directions for Teaching and Learning, 84(Winter), 73-81.

Taylor, P. G., 2000. Changing Expectations: Preparing students for Flexible Learning. The International Journal of Academic Development 5(2), pp. 107-115.

Tyler, R. W., 1949. Basic principles of curriculum and instruction. University of Chicago Press, Chicago.

West, R.E., Thomas, R. A., Bodily, R., Wright, C., and Borup, J., 2017. An analysis of instructional design and technology departments. Education Tech Research Dev 65: 869.

West, R. E., and Borup, J., 2014. An analysis of a decade of research in 10 instructional design and technology journals. British Journal of Educational Technology 45(4), pp. 545-556.

Wilson, B. G., 1996. Constructivist Learning Environments: Case Studies in Instructional design. Educational technology Publications. Englewood Cliffs NJ 


\section{AUTHOR INDEX}

Acosta Aguilera, A. ................................... 266

Ajrouh, L. ................................................ 257

Al-Ansari, M. ............................................. 139

Aldahean, E. .................................................. 49

AL-Hashimi, M. .................................. 49, 116

Alomar, M. ..................................................... 80

Alonso Secades, V. ........................... 291, 296

Al-Sartawi, A. .................................... 26, 139

Alturkistani, A. ........................................... 211

Antic, D. .................................................. 147

Araiza Vázquez, M. ................................... 271

Arranz-Garcia, O. ............................. 291, 296

Azevedo, D. ............................................... 95

Badawi, S. ....................................................26

Balaban, I. .................................................. 41

Baratè, A. .................................................. 65

Benhamed, A. ................................. 163, 179

Boukhezzar, B. .......................................... 261

Brancaccio, A. .......................................... 131

Brastad, L. .................................................. 105

Brosig Rodríguez, M. ............................... 271

Cabarcos, A. ............................................... 203

Cai, S. .................................................... 171

Car, J. .................................................... 211

Chan, C. ....................................... 11, 123

Chang, B. ................................................... 277

Chang, K. ................................................. 247

Chen, H.-L. ................................................ 352

Chuang, Y.-C. .......................................... 352

Costa, F. .................................................... 219

Dagorret, P. ............................................... 87

Dietrich, A. ................................................ 186

Edel Navarro, R. ...................................... 266

El Rassi, M. .............................................. 33

Escudeiro, P. ....................................... 219

Espejo, R. ............................................. 349

Esposito, M. .......................................... 131

Etcheverry, P. ......................................... 87

Filipovic, D. ........................................... 41

Fushikida, W. .........................................28

Galasso, B. ................................................ 219

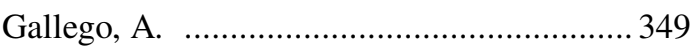

Gawlik-Kobylińska, M. ............................ 325

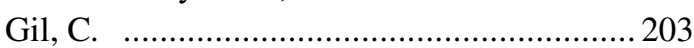

Griesbaum, J. ..............................................5 57

Gurba, K. ............................................. 235

Hamdan, A. ............. 26, 49, 116, 139, 163, 179

Haus, G.
He, S. ..................................................... 171

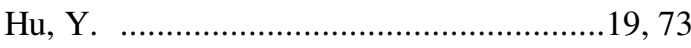

Ikhlef, A. ................................................. 261

Jang, S. ................................................... 247

Jawwad, S. .............................................. 116

Jiang, H. .................................................. 171

Joshi, S. .................................................. 105

Jovanov, G. ............................................... 147

Jovanov, N. ............................................... 147

Kappe, F. ............................................... 282

Khamis, R. …........................................... 26

Kim, Y. ................................................... 317

Komar, M. ................................................ 313

Kuneshka, L. .............................................. 333

Lam, P. ............................................11, 123

Lau, C. ............................................11, 123

Lax, J. ..................................................... 252

Lazaridou, I. ............................................... 305

Li, Y.-H. ...........................................19, 73

López Rivero, A. .......................................... 296

Lopistéguy, P. ............................................ 87

Lotter, G. ................................................. 329

Ludovico, L. ............................................... 65

Maciejewski, P. ................................... 325

Mallas, A. ........................................... 227

Mansouri, K. ............................................. 301

Mansouri, N. ............................................. 261

Marchisio, M. ....................................131, 195

Marquesuzaà, C. ........................................ 87

März, S. ................................................. 57

Mbaye, B. ….............................................. 361

Meinert, E. ............................................... 211

Morais, P. ................................................. 95

Murad, M. ....................................163, 179

Murray, K. ........................................... 211

Navarro Rangel, Y. .................................. 266

Neto, N. .................................................... 219

Niño Rodríguez, C. ................................... 271

Nodenot, T. ................................................. 87

Oura, H. .................................................. 287

Pagani, E. ................................................... 65

Pantzalis, I. ............................................... 252

Pardini, C. ............................................ 131

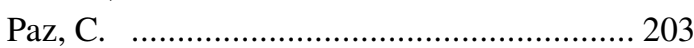

Peras, M. ............................................... 41

Pinto Lobo, M. ............................................. 337

Poirier, F. .................................................. 301

Razzaque, A. .......... 26, 49, 116, 139, 163, 179 
Reis, R.

Reyad, S.

26,139

Rimanelli, M.

235

Rozario, R.

366

Sabatier, P.

211

Sacchet, M.

131,195

Safsouf, Y.

301

Salusso, D.

Scarabottolo, N. ...........................................65

Scerbakov, A. ......................................... 282

Scerbakov, N. .......................................... 282

Slamti, K. .............................................. 257

Smyrnova-Trybulska, E. ........................... 155

So, S. ...................................................... 321

Staboulis, M. .............................................. 305

$\mathrm{Su}, \mathrm{C} .-\mathrm{Y}$. ............................................ 19, 73

Suárez, E. ................................................ 203

Synytsya, K. .......................................... 313

Teixeira, D. .......................................... 219

Teneqexhi, R. .......................................... 333

Thadathil, T. ................................................5 57

Toribio Fontenla, M. ................................... 87

Vasiljevic, J. ............................................ 147

Volkov, O. ....................................................... 313

Volosheniuk, D. ........................................... 313

Vranjes, D. ................................................ 147

Whitford, T. ............................................... 341

Wong, K. ................................................... 11

Xenos, M. ................................................... 227

$\mathrm{Xu}$, J. ......................................................... 171

Yang, Y. ................................................... 171

Yoon, J. ..................................................... 355

Yoshikawa, R. .......................................... 287

Zendrato, R. ............................................. 277 